\title{
Artificial neural network (ANN) velocity better identifies benign prostatic hyperplasia but not prostate cancer compared with PSA velocity
}

\author{
Carsten Stephan*1, Nicola Büker1, Henning Cammann², Hellmuth- \\ Alexander Meyer ${ }^{1}$, Michael Lein ${ }^{1,3}$ and Klaus Jung1,3
}

\author{
Address: ${ }^{1}$ Department of Urology, Charité - Universitätsmedizin Berlin, Germany, ${ }^{2}$ Institute of Medical Informatics, Charité - Universitätsmedizin \\ Berlin, Germany and ${ }^{3}$ Berlin Institute for Urologic Research, Germany \\ Email: Carsten Stephan* - carsten.stephan@charite.de; Nicola Büker - nicola.bueker@web.de; \\ Henning Cammann - henning.cammann@charite.de; Hellmuth-Alexander Meyer - hellmuth.meyer@charite.de; \\ Michael Lein - michael.lein@charite.de; Klaus Jung - klaus.jung@charite.de \\ * Corresponding author
}

Published: 2 September 2008

BMC Urology 2008, 8:10 doi:10.1 I86/I47|-2490-8-10

This article is available from: http://www.biomedcentral.com/I47I-2490/8/10

(c) 2008 Stephan et al; licensee BioMed Central Ltd.

This is an Open Access article distributed under the terms of the Creative Commons Attribution License (http://creativecommons.org/licenses/by/2.0), which permits unrestricted use, distribution, and reproduction in any medium, provided the original work is properly cited.
Received: 4 March 2008

Accepted: 2 September 2008

\begin{abstract}
Background: To validate an artificial neural network (ANN) based on the combination of PSA velocity (PSAV) with a \%free PSA-based ANN to enhance the discrimination between prostate cancer ( $\mathrm{PCa}$ ) and benign prostate hyperplasia (BPH).

Methods: The study comprised 199 patients with PCa $(n=49)$ or BPH $(n=150)$ with at least three PSA estimations and a minimum of three months intervals between the measurements. Patients were classified into three categories according to PSAV and ANN velocity (ANNV) calculated with the \%free based ANN "ProstataClass". Group I includes the increasing PSA and ANN values, Group 2 the stable values, and Group 3 the decreasing values.

Results: $71 \%$ of PCa patients typically have an increasing PSAV. In comparison, the ANNV only shows this in $45 \%$ of all PCa patients. However, BPH patients benefit from ANNV since the stable values are significantly more ( $83 \%$ vs. $65 \%$ ) and increasing values are less frequently (II\% vs. $21 \%$ ) if the ANNV is used instead of the PSAV.

Conclusion: PSAV has only limited usefulness for the detection of PCa with only $71 \%$ increasing PSA values, while $29 \%$ of all PCa do not have the typical PSAV. The ANNV cannot improve the PCa detection rate but may save $1 \mathrm{I}-17 \%$ of unnecessary prostate biopsies in known BPH patients.
\end{abstract}

\section{Background}

Prostate specific antigen (PSA) is accepted as screening test for prostate cancer ( $\mathrm{PCa}$ ) detection but has its limitations especially in test specificity [1]. To improve PSA specificity, many methods have been introduced, e.g. measurements of molecular forms of PSA like free PSA $[2,3]$, PSA in relation to prostate volume (PSA density,
PSAD) [4], age related reference PSA values [5] or PSA changes over time which is known as PSA velocity (PSAV) [6]. To date only the use of percent free PSA (\%fPSA) has been clinically accepted to improve specificity [7].

Recently the clinical usefulness of PSAV has debated intensively. Some authors argue for a lower cutoff for 
PSAV of $0.4 \mathrm{ng} / \mathrm{mL}$ per year instead of the former $0.75 \mathrm{ng} /$ $\mathrm{mL}$ per year cutoff especially in younger men [8]. Others introduced age adjusted PSAV and PSA cutoffs for biopsy indication [9]. For younger patients (age 50-59) the PSAV cutoff should be lowered to $0.4 \mathrm{ng} / \mathrm{mL}$ per year to improve specificity [9]. Ito et al. [10] described a yearly threshold of $0.3 \mathrm{ng} / \mathrm{mL}$ as the optimal cutoff value of PSAV if the initial PSA level is $1-1.9 \mathrm{ng} / \mathrm{mL}$ and $0.75 \mathrm{ng} /$ $\mathrm{mL}$ if the initial PSA is $2-4 \mathrm{ng} / \mathrm{mL}$. Berger et al. [11] found significant differences in PSAV between PCa and patients with no evidence of malignancy.

In contrast, two recent studies did not prove the additional value of PSAV over PSA alone $[12,13]$. When considering the large biological variability of PSA of up to $20 \%$ [14] or differences in PSA values regarding the used assay [15] this may lead to misinterpretation. Different values are even more obvious when considering \%fPSA [16-18].

An improved PCa detection rate was shown when using multivariate models like logistic regression [19] or artificial neural networks [20] which include \%fPSA, PSA, and partially patient age, prostate volume and other clinical factors as input variables. However, until now the parameter PSAV has not been included in such a multivariate model.

The aim of this study was to combine both methods, the ANN and PSAV, and to validate the diagnostic usefulness of this new model with regard to the differentiation between PCa and benign prostate hyperplasia (BPH). For that purpose, we compared the diagnostic usefulness of the conventional PSAV and other parameters with the socalled ANN velocity (ANNV) that included the PSA and free PSA velocity data into an ANN model.

\section{Methods}

From a cohort of 2959 patients visiting the Department of Urology (Charité Hospital Berlin) with total PSA (tPSA) and free PSA (fPSA) measurements from 1996-2006, a total of 199 patients were included. The selection criteria for this PSAV and ANNV study were at least three PSA and fPSA measurements with a minimum of three months interval between two measurements before treatment. All serum samples were drawn before any prostate manipulation (or at least 3-4 weeks after an earlier manipulation) and centrifuged within 2-3 hours after sampling. The samples were analyzed immediately or stored at $-20^{\circ} \mathrm{C}$ for no longer than 48 hours before assay. The study was carried out in accordance with the standards of the local ethics board and the Helsinki Declaration of 1975 as revised in 1996.
All 199 patients (44-85 years) had a histological proven diagnosis of PCa $(n=49)$ or BPH $(n=150)$ based on examination of tissue samples obtained by transrectal ultrasound (TRUS)-guided sextant (until 1999) or octant prostate biopsies. Additionally, the status of digital rectal examination (DRE), age, and prostate volume (measured by TRUS) were also available.

Total and free PSA were measured with the IMMULITE PSA and Free PSA kits (Diagnostic Products, Los Angeles, CA, USA). The analytical performance and comparisons to other PSA tests have been described earlier $[18,21]$. Prostate volume was determined by TRUS using the prolate ellipse formula. A DRE finding non-suspicious for cancer was defined as negative and a finding suspicious for cancer as positive. All patients had a complete data set on tPSA, \%fPSA, age, prostate volume, and DRE status at the time of the last PSA and fPSA measurement. In 14 of the $150 \mathrm{BPH}$ patients $(9.3 \%)$ the ANNV was not calculated using the first but the first available complete data set (fPSA and tPSA at $2^{\text {nd }}$ or $3^{\text {rd }}$ measurement) since partially the fPSA was not measured when tPSA was less than $2 \mathrm{ng} / \mathrm{mL}$ (1996-1999) or less than $1 \mathrm{ng} / \mathrm{mL}$ (1999-2006).

PSA values were included in the velocity calculation using the formula: (last PSA - first PSA)/time interval in $\mathrm{ng} / \mathrm{mL} /$ year). Based on this formula, a one year short-term-PSAV, which describes the PSAV within the last 12 months before diagnosis, was also calculated.

The ANNV was calculated analogous with the ANN output values instead of the PSA values by using the same formula (last ANN output - first ANN output/time interval). The ANN was constructed with the SPSS-module Neural connection 2.0 (SPSS) as described earlier [22]. The backpropagation network consists of one input layer with the five neurons tPSA, \% fPSA, patient age, prostate volume, and DRE status. Each ANN contains one hidden layer with three neurons. Each ANN finally contains one output neuron representing the output value as the probability of PCa. The activation function for the hidden neurons was the tanh while the activation function for the output neuron was linear in the range 0 to 1 to get a value for the probability of PCa. Training of the ANN took place in 4 steps with 100 sweeps each of them. Stopping criteria were a RMS error less than 0.001 or a rate of $95 \%$ correct classified samples. The initial weights were set randomly to values between -1 and +1 . Before training all variables were normalized to mean value 0 and standard deviation 1 and ordered randomly. To avoid over-fitting we used 10fold cross-validation. During training always $10 \%$ of the data were used for internal validation.

The respective PSA- and ANN-follow ups were divided into three groups. Group 1 consisted of increasing values 
(PSA $>0.75 \mathrm{ng} / \mathrm{mL} /$ year; ANN >4/year), group 2 of stable values (PSA - 0.75 to $0.75 \mathrm{ng} / \mathrm{mL} /$ year; ANN -4 to $4 /$ year), and group 3 of the decreasing follow up values (PSA <$0.75 \mathrm{ng} / \mathrm{mL} /$ year; ANN <-4/year). When analyzing the follow up of \%fPSA only, it has been shown that due to the large variability between the measurements there is no usefulness at all for the parameter \%fPSA velocity (data not shown).

Statistical calculations were performed with SPSS 14.0 for Windows (SPSS, Chicago, USA). We used the non-parametric Mann-Whitney U test and the Kruskal-Wallis test. The diagnostic validity of all parameters was evaluated by Receiver-operating characteristic (ROC) curve analysis. The areas under the ROC curves (AUCs) and the specificities at 90\% and 95\% sensitivity were compared by a nonparametric method using the software GraphROC 2.1 for Windows. Significance was defined as $P<0.05$.

\section{Results}

The median tPSA for the PCa patients at the time of diagnosis (last tPSA value) was $8.3 \mathrm{ng} / \mathrm{mL}$ (range $3.2-107 \mathrm{ng} /$ $\mathrm{mL})$. The BPH patients had a significantly lower $(P<$ $0.0001)$ median tPSA value of $5.3 \mathrm{ng} / \mathrm{mL}(0.4-37.1 \mathrm{ng} /$ $\mathrm{mL}$ ). Descriptive data for all analyzed tPSA ranges $0-4$, 4.1-10, 10.1-20 and >20 ng/mL for all PCa and BPH including the median tPSA, \%fPSA and prostate volume are shown in Table 1 . The median age for all patients was 68 years and the age distribution revealed no differences between the 4 tPSA groups for the PCa where the median age was 66 years (45-80 years). The median age for the $\mathrm{BPH}$ patients was somewhat but not significantly higher (68 years, range: $44-85, P=0.1$ ) but did also not differ between the 4 groups.

Regarding the follow up of the PCa patients, the number of PSA and fPSA measurements ranged from 3 to 13 (median: 4.5) whereas the BPH patients had on average more PSA and fPSA measurements (range 3 to 22, median: 7). The distribution of the follow up related to the years before diagnosis of PCa or total follow up time for the BPH patients is shown in Table 2. The median follow up time for all patients was 3.4 years while PCa patients had a shorter median follow up ( 1.8 years) compared with BPH patients ( 4.2 years).

Table 3 shows the ROC analysis for all 199 patients by comparing the AUC for tPSA, \%fPSA, PSAD, PSAV, ANN output and the ANNV. PSAD was the best parameter to differentiate between PCa and $\mathrm{BPH}$ and neither ANN nor ANNV could improve this. At 95\% sensitivity, PSAD performed better than all other parameters. On the other hand, at 95\% specificity, the ANNV was the best available parameter with a sensitivity of $32.7 \%$ and significantly better performance compared with all others except \%fPSA $(P=0.44)$. A similar behavior is seen for the 4-10 $\mathrm{ng} / \mathrm{mL}$ tPSA range in Table 4. Again, regarding the AUC comparison and the specificities at $95 \%$ sensitivity, PSAD performed best, but did only reach significance levels to all others at 95\% sensitivity but not for the AUC comparison. At 95\% specificity, the ANNV (sensitivity 37.5\%) demonstrated also within the tPSA range $4-10 \mathrm{ng} / \mathrm{mL}$ the ability to perform significantly better than all other parameters except the ANN output $(P=0.07)$. Figure 1 shows for the tPSA range $4-10 \mathrm{ng} / \mathrm{mL}$ that the ANNV has the steepest increase of the ROC curve with the highest sensitivities at 95\% and 90\% specificity, respectively. This may be more important for repeat biopsies, where biopsies in general should be avoided.

In Table 5 the respective three groups for PSAV and ANNV (increasing, stable and decreasing values) are given. More than two third of all PCa patients have the typical increasing PSAV. In comparison, the ANNV is only indicated at $45 \%$ of all PCa patients' increasing values. The differences between the PSAV and ANNV are also given in the Table 5 . It can be seen that only BPH benefit from the additional ANNV since the stable values are significantly more $(+17.4 \%)$. Also, there is a reduction of increasing values ($10.6 \%)$. This avoids repeated prostate biopsies in at least

Table I: Distribution of patients within the different PSA ranges and median values for tPSA, \%fPS and prostate volume for all patients

\begin{tabular}{|c|c|c|c|c|c|c|c|c|c|c|c|c|}
\hline \multirow[b]{2}{*}{$\begin{array}{l}\text { tPSA } \\
\text { range } \\
(\mathrm{ng} / \mathrm{mL})\end{array}$} & \multicolumn{4}{|c|}{ All patients } & \multicolumn{4}{|c|}{$\mathrm{PCa}$} & \multicolumn{4}{|c|}{$\mathrm{BPH}$} \\
\hline & number & $\begin{array}{c}\text { tPSA } \\
(\mathrm{ng} / \mathrm{mL})\end{array}$ & $\begin{array}{c}\text { \%fPSA } \\
(\%)\end{array}$ & $\begin{array}{c}\text { volume } \\
(\mathrm{ml})\end{array}$ & number & $\begin{array}{c}\text { tPSA } \\
(\mathrm{ng} / \mathrm{mL})\end{array}$ & $\begin{array}{c}\text { \%fPSA } \\
(\%)\end{array}$ & $\begin{array}{l}\text { volume } \\
(\mathrm{ml})\end{array}$ & number & $\begin{array}{c}\text { tPSA } \\
(\mathrm{ng} / \mathrm{mL})\end{array}$ & $\begin{array}{c}\text { \%fPSA } \\
(\%)\end{array}$ & $\begin{array}{c}\text { volume } \\
(\mathrm{ml})\end{array}$ \\
\hline $0-4$ & 47 & 2.1 & 19.4 & 40 & 2 & 3.5 & 17.2 & 36.5 & 45 & 2.1 & 19.5 & 40 \\
\hline $4.1-10$ & 94 & 5.6 & 15.9 & 44.5 & 24 & 5.8 & $14.3^{*}$ & $33.5^{*}$ & 70 & 5.6 & 17.4 & 50 \\
\hline $10.1-20$ & 50 & 13.6 & II & 49.1 & 20 & 13.5 & $9.7^{*}$ & $44.5^{*}$ & 30 & 13.9 & 13.7 & 59 \\
\hline$>20$ & 8 & 25.7 & 9 & 35.5 & 3 & 29.3 & $6.8^{*}$ & $35^{*}$ & 5 & 25.6 & 11 & 80 \\
\hline all & 199 & 6.2 & 15.1 & 45 & 49 & $8.3^{*}$ & $10.9 *$ & $35^{*}$ & 150 & 5.3 & 16.7 & 47 \\
\hline
\end{tabular}

*significantly different from BPH patients with $P<0.000$ I 
Table 2: PSA follow up for all patients for all patient groups

\begin{tabular}{|c|c|c|c|c|c|c|}
\hline \multirow[b]{2}{*}{ Follow up (years) } & \multicolumn{2}{|c|}{ all patients } & \multicolumn{2}{|c|}{$\mathrm{PCa}$} & \multicolumn{2}{|c|}{$\mathrm{BPH}$} \\
\hline & number & percentage in $\%$ & number & percentage in \% & number & percentage in \% \\
\hline 0.5 to 1 & 12 & 6 & 6 & 12 & 6 & 4 \\
\hline I to 2 & 47 & 24 & 21 & 43 & 26 & 18 \\
\hline 2 to 4 & 56 & 28 & 15 & 31 & 41 & 27 \\
\hline 4 to 6 & 41 & 20.5 & 5 & 10 & 36 & 24 \\
\hline 6 to 9 & 43 & 21.5 & 2 & 4 & 41 & 27 \\
\hline all & 199 & 100 & 49 & 100 & 150 & 100 \\
\hline
\end{tabular}

$11 \%$ of all BPH patients. Another observation is that more than half of all patients (52\%) show an atypical PSAV with regard to their diagnosis.

When using the traditional PSAV cutoff of $0.75 \mathrm{ng} / \mathrm{mL} /$ year the regular median PSAV for the PCa patients was $1.24 \mathrm{ng} / \mathrm{mL} /$ year whereas the PSAV for the BPH patients was $0.16 \mathrm{ng} / \mathrm{mL} /$ year $(P<0.0001)$. Further descriptive data are given for the patients with increasing, stable and decreasing PSAV (Table 6) and ANNV (Table 7).

When analyzing the short-term-PSAV over 12 months, the median PSAV for the PCa patients is higher with $1.61 \mathrm{ng} /$ $\mathrm{mL} /$ year but the median PSAV for the BPH patients is almost zero with $0.04 \mathrm{ng} / \mathrm{mL} /$ year $(P=0.0001)$. There are only slight differences between PCa patients when looking at the PSAV for a 12 months period (data not shown). However, around one third of all BPH patients change the status of stable values which were visible over a long time observation to increasing or decreasing values when only calculating the PSAV over 12 months. Instead of $65 \%$ by using the regular PSAV, only $32 \%$ of all BPH patients had stable values when using the short-term-PSAV.

\section{Discussion}

The discussion regarding the use of PSAV to improve the low specificity of PSA has gained increasing attention. Initially, Carter et al. [6] presented at a PSAV cut off of 0.75 $\mathrm{ng} / \mathrm{mL} /$ year a specificity of $90 \%$ - significantly higher than the $60 \%$ specificity of a single PSA cutoff of $4 \mathrm{ng} / \mathrm{mL}$. The results, though, were based on analyzing only 18 cancer cases [6]. In a current analysis on a large cohort of patients the authors found that the PSAV cutoff of 0.75 $\mathrm{ng} / \mathrm{mL} /$ year underestimated the risk of PCa especially in younger men and recommended age-adjusted cutoffs [9]. However, this analysis excluded $45 \%$ of men $(5,381$ from 11,861 men) with a PSAV of 0 or less and 30\% (504 from 1654) PCa patients without increasing PSAV. The remaining $70 \%$ PCa patients had an increasing PSAV, which is the same percentage of PCa patients as we found in our

Table 3: Areas under the curves (AUC), specificities at $95 \%$ sensitivity and sensitivities at $95 \%$ specificity with the respective confidence intervals (in parenthesis) for the parameters tPSA, \%fPSA, PSAD\$, PSAV, ANN and ANNV $\$$ for all patients $(n=199)$

\begin{tabular}{|c|c|c|c|c|c|c|}
\hline Parameter & $\begin{array}{c}\text { AUC } \\
\text { (Confidence } \\
\text { Intervals) }\end{array}$ & $\begin{array}{c}\text { P-values and } \\
\text { significance levels§ }\end{array}$ & $\begin{array}{l}\text { Specificity at } 95 \% \\
\text { Sensitivity }\end{array}$ & $\begin{array}{c}\text { P-values and } \\
\text { significance levels }\end{array}$ & $\begin{array}{l}\text { Sensitivity at } 95 \% \\
\text { Specificity }\end{array}$ & $\begin{array}{c}\text { P-values and } \\
\text { significance levels } \$\end{array}$ \\
\hline PSA & $\begin{array}{c}0.69 \\
(0.61-0.77)\end{array}$ & $0.0001 * *$ & $\begin{array}{c}27.3 \\
(21.4-34)\end{array}$ & $<0.0001 * * *$ & $\begin{array}{c}14.3 \\
(7-25.4)\end{array}$ & $0.008^{* *}$ \\
\hline \%fPSA & $\begin{array}{c}0.70 \\
(0.71-0.78)\end{array}$ & $0.007^{* *}$ & $\begin{array}{c}17.3 \\
(12.5-23.3)\end{array}$ & $<0.0001 * * *$ & $\begin{array}{c}20.4 \\
(11.6-32.3)\end{array}$ & 0.44 \\
\hline PSAD & $\begin{array}{c}0.76 \\
(0.69-0.83)\end{array}$ & - & $\begin{array}{c}44 \\
(37.1-5 \mid .7)\end{array}$ & - & $\begin{array}{c}16.3 \\
(8.5-27.7)\end{array}$ & $0.013^{*}$ \\
\hline PSAV & $\begin{array}{c}0.76 \\
(0.67-0.84)\end{array}$ & 0.835 & $\begin{array}{c}4.7 \\
(2.2-8.7)\end{array}$ & $<0.0001 * * *$ & $\begin{array}{c}16.3 \\
(8.5-27.7)\end{array}$ & $0.023^{*}$ \\
\hline ANN & $\begin{array}{c}0.66 \\
(0.57-0.75)\end{array}$ & $0.00 I^{* *}$ & $\begin{array}{c}10 \\
(6.3-15.1)\end{array}$ & $<0.0001^{* * * *}$ & $\begin{array}{c}18.4 \\
(10-30)\end{array}$ & $0.023 *$ \\
\hline ANNV & $\begin{array}{c}0.56 \\
(0.44-0.68)\end{array}$ & $<0.0001 * * * *$ & $\begin{array}{c}1.3 \\
(0.2-4.3)\end{array}$ & $<0.0001^{* * * *}$ & $\begin{array}{c}32.7 \\
(21.7-45.4)\end{array}$ & - \\
\hline
\end{tabular}

\$PSAD with largest AUC and highest specificity at $95 \%$ sensitivity, all others compared to PSAD

$\$ A N N V$ with highest sensitivity at $95 \%$ specificity, all others compared to ANNV

$* P<0.05$

$* * P<0.01$

$* * * P<0.0001$ 
Table 4: Areas under the curves (AUC), specificities at $95 \%$ sensitivity and sensitivities at $95 \%$ specificity with the respective confidence intervals (in parenthesis) for the parameters tPSA, \%fPSA, PSAD\$, PSAV, ANN and ANNV\$ for the tPSA range 4- $10 \mathrm{ng} / \mathrm{mL}(\mathrm{n}=94)$

\begin{tabular}{|c|c|c|c|c|c|c|}
\hline Parameter & $\begin{array}{l}\text { AUC } \\
\text { (Confidence } \\
\text { Intervals) }\end{array}$ & $\begin{array}{c}\text { P-values and } \\
\text { significance levels } \S\end{array}$ & $\begin{array}{l}\text { Specificity at } 95 \% \\
\text { Sensitivity }\end{array}$ & $\begin{array}{c}\text { P-values and } \\
\text { significance levels§}\end{array}$ & $\begin{array}{c}\text { Sensitivity at } 95 \% \\
\text { Specificity }\end{array}$ & $\begin{array}{c}\text { P-values and } \\
\text { significance levels\$ }\end{array}$ \\
\hline PSA & $\begin{array}{c}0.50 \\
(0.36-0.63)\end{array}$ & $<0.0001 * * *$ & $\begin{array}{c}11.4 \\
(5.9-19.8)\end{array}$ & $0.002^{* *}$ & $\begin{array}{c}4.2 \\
(1.3-19.1)\end{array}$ & $0.037^{*}$ \\
\hline \%fPSA & $\begin{array}{c}0.64 \\
(0.5 I-0.77)\end{array}$ & 0.09 & $\begin{array}{c}20 \\
(12.6-29.6)\end{array}$ & $0.045^{*}$ & $\begin{array}{c}12.5 \\
(3.5-29.7)\end{array}$ & $0.023 *$ \\
\hline PSAD & $\begin{array}{c}0.69 \\
(0.58-0.81)\end{array}$ & - & $\begin{array}{c}35.7 \\
(26.2-46.2)\end{array}$ & - & $\begin{array}{c}4.2 \\
(1.3-19.1)\end{array}$ & $0.013 *$ \\
\hline PSAV & $\begin{array}{c}0.66 \\
(0.53-0.80)\end{array}$ & 0.529 & $\begin{array}{c}4.3 \\
(1.2-11.0)\end{array}$ & $<0.0001 * * *$ & $\begin{array}{c}12.5 \\
(3.5-29.7)\end{array}$ & $0.023 *$ \\
\hline ANN & $\begin{array}{c}0.66 \\
(0.53-0.79)\end{array}$ & 0.264 & $\begin{array}{c}8.6 \\
(3.8-16.4)\end{array}$ & $<0.0001 * * *$ & $\begin{array}{c}16.7 \\
(5.9-34.6)\end{array}$ & 0.074 \\
\hline ANNV & $\begin{array}{c}0.57 \\
(0.40-0.75)\end{array}$ & $0.008 * *$ & 0 & $<0.0001 * * *$ & $\begin{array}{c}37.5 \\
(21.2-56.4)\end{array}$ & - \\
\hline
\end{tabular}

\$PSAD with largest AUC and highest specificity at $95 \%$ sensitivity, all others compared to PSAD

$\$ A N N V$ with highest sensitivity at $95 \%$ specificity, all others compared to ANNV

$* P<0.05$

$* * P<0.01$

$* * * P<0.0001$

study with increasing PSA values (Table 5). However, in our analysis, all patients regardless of the PSAV were considered. On the other hand, 30\% of all PCa patients do not present with the typical increasing PSA values. $10 \%$ of

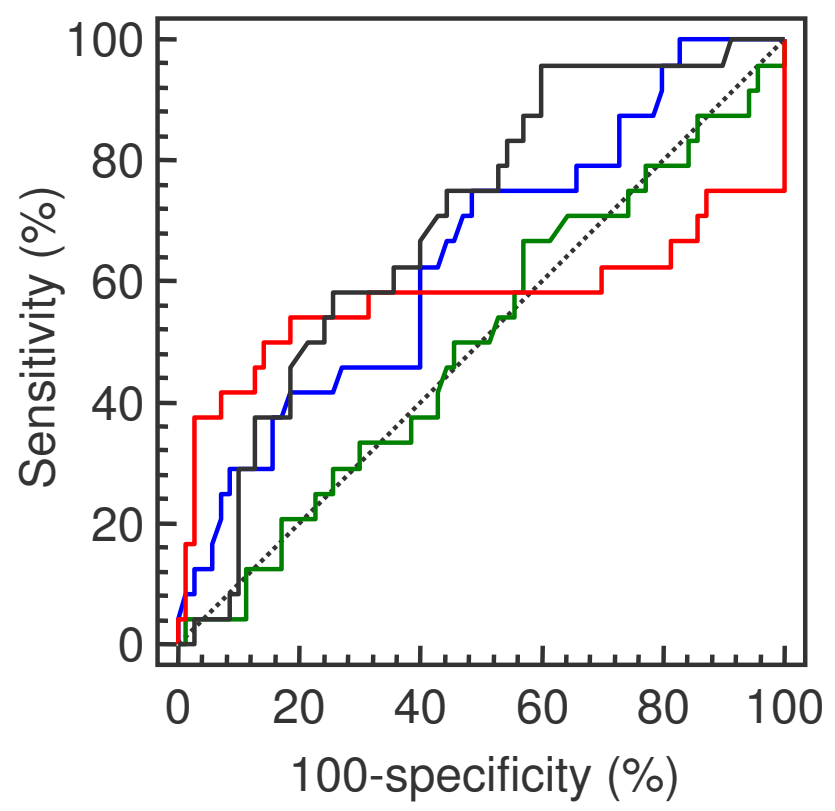

Figure I

ROC curves for tPSA (green, AUC 0.5), \%fPSA (blue, AUC 0.64), PSAD (black, AUC 0.69) and ANNV (red, AUC 0.57) to show the different behavior of the curve regardless of the AUC at tPSA 4-10 ng/mL (PSAV and ANN not shown, given in table 4). all PCa patients even have decreasing PSA values. This shows that PSAV can detect approximately $2 / 3$ of all PCa patients but stable or decreasing PSA values do not really reduce the risk of having PCa if the PSA alone is elevated.

It was assumed that additional clinical and laboratory data would improve the PCa detection rate when using ANN models where \%fPSA, age, prostate volume and the DRE status are considered. However, this study could not demonstrate a positive effect by using the ANNV to detect more cancer patients since only $45 \%$ of all PCa patient had an increasing ANNV. This is a reduction of $26.5 \%$ compared with the PSAV. The number of stable or decreasing ANNV output values increased compared with the PSAV indicating that PSAV alone is the better indicator for a PCa risk. More than half of all PCa patients had a stable or even decreasing ANNV. It should be noted that this poor performance of the ANN is only related to the follow up but not to the ANN use at all for PCa detection. Here it has been demonstrated that ANN models with clinical and laboratory values can significantly improve the PCa detection rate compared with PSA and \%fPSA [20,22-25]. However, the relatively small number of patients with only one third PCa is a limitation of this study compared with other ANN studies where no follow up was analyzed.

Importantly, the inclusion of the ANNV can substantially save repeated biopsies in BPH patients. Whereas the PSAV shows only for $65.3 \%$ of the BPH patients the typical continuous follow up, this number increases to $82.7 \%$ when using the ANNV. Thus, at the best case approximately $17 \%$ of all BPH patients may benefit if taking into account not only the PSA but also the ANN follow up. When only 
Table 5: Comparison of the PSA and ANN velocity in PCa and BPH patients

\begin{tabular}{lcccccc}
\hline & \multicolumn{3}{c}{ PSA velocity (PSAV) } & \multicolumn{3}{c}{ ANN velocity (ANNV) } \\
\hline follow up group & $\begin{array}{c}\text { PCa in \% } \\
(\mathrm{n}=49)\end{array}$ & $\begin{array}{c}\text { BPH in } \% \\
(\mathrm{n}=150)\end{array}$ & $\begin{array}{c}\text { PCa in } \% \\
(\mathrm{n}=49)\end{array}$ & $\begin{array}{c}\text { Difference to PSAV } \\
\text { BPH in \% } \\
(\mathrm{n}=150)\end{array}$ & Difference to PSAV \\
\hline increasing & $71.4 \%$ & $21.3 \%$ & $44.9 \%$ & $-26.5 \%$ & $10.7 \%$ & $-10.6 \%$ \\
stable* & $18.4 \%$ & $65.3 \%$ & $34.7 \%$ & $+16.3 \%$ & $82.7 \%$ & $-17.4 \%$ \\
decreasing & $10.2 \%$ & $13.3 \%$ & $20.4 \%$ & $+10.2 \%$ & $6.7 \%$ & $-6.6 \%$ \\
\hline
\end{tabular}

*by using the cutoff of $0.75 \mathrm{ng} / \mathrm{mL} /$ year for tPSA (range -0.75 to 0.75 ) and by using the cutoff of 4 per year for ANN output (range -4 to 4 )

looking at the difference between an increasing PSAV and increasing ANNV, the ANNV could save approximately $11 \%$ of all biopsies compared with the PSAV. As seen in Figure 1, the ANNV has the highest sensitivities at 95\% and $90 \%$ specificity, respectively. Thus, relatively good sensitivity values at high specificity cutoffs argue for a usability of the ANNV especially for repeat biopsies, where biopsies in general should be avoided. This is an important result of the study. A further possibility is to look at partial ROC areas, which has been published before [26]. When only including the AUC between $80 \%$ and $100 \%$ specificity, the ANNV has clearly the largest AUC compared with all others. Hence, for a ROC comparison one should not only consider the AUC but also the ROC curve shape for a better interpretation.

Another problem is the relatively poor performance of the PSAV alone, which can be partially explained by the biological variation of PSA of up to $20 \%$ [14]. Differences in PSA values regarding the used assays may be also responsible [15]. However, this could be excluded in our study since only the IMMULITE assays were used for the tPSA and PPSA measurements over the whole time period from 1996 until 2006. The use of \%fPSA revealed large differences between commonly used assays [16-18]. In a recent study on 4,480 men in 5 different populations with 5 different PSA and fPSA assays and the application of different assay-adapted ANNs it has been demonstrated that our recently multicentric evaluated ANN "ProstataClass" [22] should not be used without consideration of the PSA assay [25]. In another study, Okamura and colleagues [27] reported an acceptable comparability between two PSA assays by using a \%fPSA-based logistic regression model.

To calculate the PSAV we subdivided the PSA follow ups into three categories with increasing $(>0.75 \mathrm{ng} / \mathrm{mL} /$ year $)$, stable (-0.75 to $0.75 \mathrm{ng} / \mathrm{mL} /$ year) and decreasing (<- -0.75 $\mathrm{ng} / \mathrm{mL} /$ year) values. The same procedure was performed with the ANNV, where 4/year was taken as cutoff. Contrary to others [28], we found it difficult to further subdivide also the category of inconsistent values. We did not find it useful to determine a definitive cutoff for the ANNV as Carter et al. [6] did for the PSAV but the cutoff $4 /$ year for the ANNV was taken for this preliminary study which equals to $90 \%$ specificity to have the possibility to discriminate between increasing, stable and decreasing values. However, the number of patients is relatively small and the usefulness of a cutoff especially for the PCa detection has not been shown.

Recently, a study has reported that different methods to calculate the PSAV either with simple arithmetic or linear regression does not change the outcome [29]. Data from

Table 6: Median values and p-values between the 3 groups of increasing, stable or decreasing PSAV values

\begin{tabular}{|c|c|c|c|c|c|c|c|c|c|}
\hline \multirow[b]{2}{*}{ Parameter } & \multicolumn{3}{|c|}{$\begin{array}{l}\text { Increasing PSAV } \\
(>0.75 \mathrm{ng} / \mathrm{mL} / \text { year })\end{array}$} & \multicolumn{3}{|c|}{$\begin{array}{l}\text { Stable PSAV } \\
(-0.75 \text { to } 0.75 \mathrm{ng} / \mathrm{mL} / \text { year })\end{array}$} & \multicolumn{3}{|c|}{$\begin{array}{l}\text { Decreasing PSAV } \\
(<-0.75 \mathrm{ng} / \mathrm{mL} / \text { year })\end{array}$} \\
\hline & $\mathrm{PCa}(\mathrm{n}=35)$ & $\mathrm{BPH}(\mathrm{n}=32)$ & $\mathrm{p}$-value & $\mathrm{PCa}(\mathrm{n}=9)$ & $\mathrm{BPH}(\mathrm{n}=98)$ & $\mathrm{P}$-value & $\mathrm{PCa}(\mathrm{n}=5)$ & $\mathrm{BPH}(\mathrm{n}=20)$ & $\mathrm{p}$-value \\
\hline Age (years) & 65 & 68 & 0.15 & 68 & 68 & 0.86 & 72 & 68.5 & 0.92 \\
\hline tPSA (ng/mL) & $11.7^{*}$ & $11.5^{* \$}$ & 0.72 & $4.8 \S$ & 4.96 & 0.96 & $6.2 *$ & 4.39 & 0.067 \\
\hline \%fPSA (\%) & $9.6 * \S$ & 14.1 & 0.001 & 15 & 17.4 & 0.49 & 21 & 16 & 0.13 \\
\hline Volume (mL) & 35 & 46.5 & 0.066 & 33 & 45 & 0.1 & 55 & 57.5 & 0.89 \\
\hline
\end{tabular}

The p-value is given for the comparison between the respective PCa and BPH patients (Mann-Whitney $U$ Test)

*significantly different to the respective patients in the stable group $(P<0.05$; Mann-Whitney $U$ Test $)$

ssignificantly different to the respective patients in the decreasing group $(P<0.05 ;$ Mann-Whitney $U$ Test $)$

The Kruskal-Wallis Test for the PCa patients between all 3 groups showed for tPSA $(p=0.0003)$ and \%fPS $(p=0.0008)$ significant differences but not for age $(p=0.26)$ or volume $(p=0.17)$.

The Kruskal-Wallis Test for the BPH patients between all 3 groups showed for tPSA $(p<0.000 \mathrm{I})$ significant differences but not for \% fPSA $(p=0.4)$, age $(p=0.96)$ or volume $(p=0.44)$. 
Table 7: Median values and p-values between the 3 groups of increasing, stable or decreasing ANNV values

\begin{tabular}{|c|c|c|c|c|c|c|c|c|c|}
\hline \multirow[b]{2}{*}{ Parameter } & \multicolumn{3}{|c|}{ Increasing ANNV $(>4)$} & \multicolumn{3}{|c|}{ Stable ANNV (-4 to 4$)$} & \multicolumn{3}{|c|}{ Decreasing ANNV $(<-4)$} \\
\hline & $\mathrm{PCa}(\mathrm{n}=22)$ & $\mathrm{BPH}(\mathrm{n}=16)$ & $\mathrm{p}$-value & $\mathrm{PCa}(\mathrm{n}=17)$ & $\mathrm{BPH}(\mathrm{n}=124)$ & $\mathrm{p}$-value & $\mathrm{PCa}(\mathrm{n}=10)$ & $\mathrm{BPH}(\mathrm{n}=10)$ & P-value \\
\hline Age (years) & $65^{*}$ & 68.5 & 0.61 & 70 & 68 & 0.7 & 62 & 64 & 0.29 \\
\hline tPSA (ng/mL) & 8.3 & 6.8 & 0.17 & 10.2 & 5.3 & 0.002 & 5.5 & 4.35 & 0.5 \\
\hline \%fPSA (\%) & $8.0 * \$$ & 13.15 & 0.017 & 15.15 & 17.4 & 0.85 & 11.2 & 13.8 & 0.1 \\
\hline Volume (mL) & $33.5^{*}$ & $36.5^{*}$ & 0.34 & 50 & $53.5^{\$}$ & 0.87 & $30.5^{*}$ & $34 *$ & 0.26 \\
\hline
\end{tabular}

The $\mathrm{p}$-value is given for the comparison between the respective PCa and BPH patients (Mann-Whitney $\cup$ Test)

*significantly different to the respective patients in the stable group $(P<0.05$; Mann-Whitney $\cup$ Test $)$

$\S$ significantly different to the respective patients in the decreasing group $(P<0.05$; Mann-Whitney $\cup$ Test $)$

The Kruskal-Wallis Test for the PCa patients between all 3 groups showed only for \%fPSA $(p=0.014)$ significant differences but not for age $(p=$

$0.32)$, tPSA $(p=0.16)$ or volume $(p=0.98)$.

The Kruskal-Wallis Test for the BPH patients between all 3 groups showed for volume $(p=0.022)$ significant differences but not for age $(p=0.3 \mathrm{I})$, tPSA $(p=0.61)$ or \% fPSA $(p=0.17)$.

this study were also not different when using the linear regression calculated compared with the arithmetic method (not shown).

Whereas the advantage of ANN models compared with PSA or \%fPSA has been proven in many studies [20,22], the situation for PSAV compared with PSA is unclear $[8,11-13,30,31]$. Studies on large populations have shown a clear advantage for PSAV compared with PSA alone $[8,11,31]$. Apart from PSAV, the age and the tPSA range should be also considered $[8,31]$. Another study in screened men proved a significant difference for the PSAV between PCa (median: 0.62) and men with a negative biopsy (median: 0.46) but could not confirm a clinical advantage [30]. Furthermore, the studies by Thompson et al. [13] and Schroeder et al. [12] also on large populations, did not show any advantage of using PSAV instead of PSA. In a recent review on studies of PSAV it was explained why the association between PSAV and diseasespecific survival, which has been shown in other studies, does not necessarily imply that PSAV will be a useful screening tool [32]. Moreover, other results show that patients who have a PSA which returns to normal levels still have a significant risk of PCa which led the authors to the conclusion that prostate biopsy might be most appropriate even after a single abnormal PSA [28]. Here we only partially agree because a simple repeated measurement of the PSA can avoid a significant number of biopsies and inclusion of ANN models give further certainty for a correct biopsy indication [33].

\section{Conclusion}

To conclude, this study demonstrates limited usefulness of PSAV to detect PCa with only $71 \%$ of increasing PSA values while approximately $30 \%$ of all PCa do not have the typical PSA follow up. The ANNV cannot improve the PCa detection rate but may save $11-17 \%$ of unnecessary prostate biopsies in BPH patients. Further studies on screening and larger populations are needed to determine the usefulness of the ANNV.

\section{Abbreviations}

ANN: artificial neural network; ANNV: ANN velocity; BPH: benign prostatic hyperplasia; DRE: digital rectal examination; fPSA: free PSA; PCa: prostate cancer; PSA: prostate-specific antigen; PSAD: PSA density; PSAV: PSA velocity; percent free PSA; tPSA: total PSA; TRUS: transrectal ultrasound

\section{Competing interests}

The authors declare that they have no competing interests.

\section{Authors' contributions}

All authors read and approved the final manuscript.

\section{Acknowledgements}

This work was supported by Diagnostics Products Corp. and by the Berliner Sparkassenstiftung Medizin. We gratefully thank Paul EC Sibley for his helpful corrections.

\section{References}

I. Polascik TJ, Oesterling JE, Partin AW: Prostate specific antigen: a decade of discovery-what we have learned and where we are going. J Urol 1999, I 62:293-306.

2. Lilja H, Christensson A, Dahlen U, Matikainen MT, Nilsson O, Pettersson K, Lövgren T: Prostate-specific antigen in serum occurs predominantly in complex with alpha I-antichymotrypsin. Clin Chem 1991, 37:1618-1625.

3. Stenman UH, Leinonen J, Alfthan $\mathrm{H}$, Rannikko S, Tuhkanen K, Alfthan $\mathrm{O}$ : A complex between prostate-specific antigen and alpha Iantichymotrypsin is the major form of prostate-specific antigen in serum of patients with prostatic cancer: assay of the complex improves clinical sensitivity for cancer. Cancer Res |99|, 51:222-226.

4. Benson MC, Whang IS, Pantuck A, Ring K, Kaplan SA, Olsson CA, Cooner WH: Prostate specific antigen density: a means of distinguishing benign prostatic hypertrophy and prostate cancer. J Urol 1992, 147:815-816.

5. Oesterling JE, Jacobsen SJ, Chute CG: Serum prostate-specific antigen in a community-based population of healthy men: establishment of age-specific reference ranges. JAMA 1993, 270:860-866 
6. Carter HB, Pearson JD: PSA velocity for the diagnosis of early prostate cancer. A new concept. Urol Clin North Am 1993, 20:665-670.

7. Catalona W], Partin AW, Slawin KM, Brawer MK, Flanigan RC, Patel A, Richie JP, deKernion JB, Walsh PC, Scardino PT, Lange PH, Subong EN, Parson RE, Gasior GH, Loveland KG, Southwick PC: Use of the percentage of free prostate-specific antigen to enhance differentiation of prostate cancer from benign prostatic disease: a prospective multicenter clinical trial. JAMA 1998, 279: I542-I547.

8. Loeb S, Roehl KA, Catalona WJ, Nadler RB: Prostate specific antigen velocity threshold for predicting prostate cancer in young men. J Urol 2007, I77:899-902.

9. Moul JW, Sun L, Hotaling JM, Fitzsimons NJ, Polascik TJ, Robertson CN, Dahm P, Anscher MS, Mouraviev V, Pappas PA, Albala DM: Age adjusted prostate specific antigen and prostate specific antigen velocity cut points in prostate cancer screening. J Urol 2007, I77:499-503.

10. Ito K, Yamamoto T, Ohi M, Kubota Y, Fukabori Y, Kurokawa K, Suzuki K, Yamanaka H: Usefulness of prostate-specific antigen velocity in screening for prostate cancer. Int J Urol 2002, 9:316-32|

II. Berger AP, Deibl M, Strasak A, Bektic J, Pelzer AE, Klocker H, Steiner $H$, Fritsche G, Bartsch G, Horninger W: Large-scale study of clinical impact of PSA velocity: long-term PSA kinetics as method of differentiating men with from those without prostate cancer. Urology 2007, 69:134-138.

12. Schroder FH, Roobol MJ, van der Kwast TH, Kranse R, Bangma CH: Does PSA velocity predict prostate cancer in pre-screened populations? Eur Urol 2006, 49:460-465.

13. Thompson IM, Ankerst DP, Chi C, Goodman PJ, Tangen CM, Lucia MS, Feng Z, Parnes HL, Coltman CA Jr.: Assessing prostate cancer risk: results from the Prostate Cancer Prevention Trial. J Natl Cancer Inst 2006, 98:529-534.

14. Soletormos G, Semjonow A, Sibley PE, Lamerz R, Petersen PH, Albrecht W, Bialk P, Gion M, Junker F, Schmid HP, Van Poppel H: Biological variation of total prostate-specific antigen: a survey of published estimates and consequences for clinical practice. Clin Chem 2005, 5 I: 1342-1351.

15. Semjonow A, De Angelis G, Oberpenning F, Schmid HP, Brandt B, Hertle L: The clinical impact of different assays for prostate specific antigen. BJU Int 2000, 86:590-597.

16. Blijenberg BG, Yurdakul G, Van Zelst BD, Bangma CH, Wildhagen MF, Schroder FH: Discordant performance of assays for free and total prostate-specific antigen in relation to the early detection of prostate cancer. BJU Int 200I, 88:545-550.

17. Kort SA, Martens F, Vanpoucke $H$, van Duijnhoven $H L$, Blankenstein MA: Comparison of 6 Automated Assays for Total and Free Prostate-Specific Antigen with Special Reference to Their Reactivity toward the WHO $96 / 670$ Reference Preparation. Clin Chem 2006, 52:1568-I574.

18. Stephan C, Klaas M, Muller C, Schnorr D, Loening SA, Jung K: Interchangeability of measurements of total and free prostatespecific antigen in serum with 5 frequently used assay combinations: an update. Clin Chem 2006, 52:59-64

19. Virtanen A, Gomari M, Kranse R, Stenman UH: Estimation of prostate cancer probability by logistic regression: free and total prostate-specific antigen, digital rectal examination, and heredity are significant variables. Clin Chem 1999, 45:987-994.

20. Finne P, Finne R, Auvinen A, Juusela $H$, Aro J, Maattanen L, Hakama M, Rannikko S, Tammela TL, Stenman U: Predicting the outcome of prostate biopsy in screen-positive men by a multilayer perceptron network. Urology 2000, 56:418-422.

21. Jung $K$, Stephan $C$, Lein $M$, Henke $W$, Schnorr D, Brux B, Schürenkämper P, Loening SA: Analytical performance and clinical validity of two free prostate-specific antigen assays compared. Clin Chem 1996, 42:1026-1033.

22. Stephan C, Cammann H, Semjonow A, Diamandis EP, Wymenga LFA, Lein M, Sinha $P$, Loening SA, Jung K: Multicenter evaluation of an artificial neural network to increase prostate cancer detection rate and reduce unnecessary biopsies. Clin Chem 2002, 48: $1279-1287$

23. Stephan C, Xu C, Brown DA, Breit SN, Michael A, Nakamura T, Diamandis EP, Meyer $H$, Cammann H, Jung K: Three new serum markers for prostate cancer detection within a percent free PSA-based artificial neural network. Prostate 2006, 66:65I-659.
24. Stephan C, Meyer HA, Kwiatkowski M, Recker F, Cammann H, Loening SA, Jung K, Lein M: A (-5, -7) ProPSA Based Artificial Neural Network to Detect Prostate Cancer. Eur Urol 2006, 50:1014-1020.

25. Stephan C, Xu C, Cammann H, Graefen M, Haese A, Huland H, Semjonow A, Diamandis EP, Remzi M, Djavan B, Wildhagen MF, Blijenberg BG, Finne P, Stenman UH, Jung K, Meyer HA: Assay-specific artificial neural networks for five different PSA assays and populations with PSA $2-10 \mathrm{ng} / \mathbf{m l}$ in $\mathbf{4 , 4 8 0}$ men. World J Urol 2007, 25:95-103.

26. Gjengsto P, Paus E, Halvorsen OJ, Eide J, Akslen LA, Wentzel-Larsen T, Hoisaeter PA: Predictors of prostate cancer evaluated by receiver operating characteristics partial area index: a prospective institutional study. J Urol 2005, 173:425-428.

27. Okamura $\mathrm{K}$, Takaba $\mathrm{H}$, Kamihira O, Kinukawa $\mathrm{T}$, Ono $\mathrm{Y}$, Ohshima $\mathrm{S}$, Nagasaka T: Determination of the relative probability for prostate cancer to avoid unnecessary biopsy. Int J Urol 2005 1 2:346-352.

28. Connolly D, Black A, Nambirajan T, Murray LJ, Gavin A, Keane PF: Can PSA patterns be used to identify men with prostate cancer? Eur Urol Suppl 2006, 5(2):237-237.

29. Yu X, Han M, Loeb S, Gashti SN, Yeh JT, Roehl KA, Catalona WJ: Comparison of methods for calculating prostate specific antigen velocity. J Urol 2006, I76:2427-243I.

30. Raaijmakers R, Wildhagen MF, Ito K, Paez A, de Vries SH, Roobol MJ, Schroder FH: Prostate-specific antigen change in the European Randomized Study of Screening for Prostate Cancer, section Rotterdam. Urology 2004, 63:316-320.

3I. Yu X, Loeb S, Roehl KA, Han M, Catalona WJ: The association between total prostate specific antigen concentration and prostate specific antigen velocity. J Urol 2007, I77: | 298-| 302

32. Etzioni RD, Ankerst DP, Weiss NS, Inoue LY, Thompson IM: Is Prostate-Specific Antigen Velocity Useful in Early Detection of Prostate Cancer? A Critical Appraisal of the Evidence. J Nat Cancer Inst 2007, 99:I5I0-I5I5.

33. Stephan C, Lein M, Schnorr D, Loening SA, Jung K: Repeating the measurement of prostate-specific antigen in symptomatic men can avoid unnecessary prostatic biopsy. BJU Int 2004, 93:|360-|36|.

\section{Pre-publication history}

The pre-publication history for this paper can be accessed here:

http://www.biomedcentral.com/1471-2490/8/10/prepub

Publish with Bio Med Central and every scientist can read your work free of charge

"BioMed Central will be the most significant development for disseminating the results of biomedical research in our lifetime. "

Sir Paul Nurse, Cancer Research UK

Your research papers will be:

- available free of charge to the entire biomedical community

- peer reviewed and published immediately upon acceptance

- cited in PubMed and archived on PubMed Central

- yours - you keep the copyright

Submit your manuscript here:

http://www.biomedcentral.com/info/publishing_adv.asp
BioMedcentral 